Agrovoc descriptors: chicory, cichorium intybus, aeroponics, protected cultivation, selenium, plant nutrition, nutrient uptake, nutrient intake, proximate composition, mineral content, mineral deficiencies

Agris category code: F61, Q04

\title{
Selenium uptake and distribution in chicory (Cichorium intybus L.) grown in an aeroponic system
}

\author{
Vekoslava STIBILJ $^{1 *}$, Polona SMRKOLJ ${ }^{1,2}$, Radojko JAĆIMOVIĆ ${ }^{1}$, Jože OSVALD ${ }^{3}$
}

Received: February 15, 2011; accepted: August 19, 2011.

Delo je prispelo 15. februarja 2011, sprejeto 19. avgusta 2011.

\begin{abstract}
Cultivated plants generally are a poor source of dietary selenium $(<0.1 \mathrm{mg} / \mathrm{kg}$ wet weight). In this work the influence of sodium selenate on selenium distribution in the chicory (Cichorium intybus L.) cultivars 'Anivip' and 'Monivip' was studied in an aeroponic system in a greenhouse. The plants roots were moistened every fifteen minutes with a Resh nutrient solution with added selenium $\left(10 \mathrm{mg} \mathrm{L}^{-1}\right)$ in the form of sodium selenate. The content of total selenium in chicory roots and leaves was studied after different periods of time and different temperatures of exposure to the selenium enriched nutrient solution. In two separate experiments chicory was treated with selenium enriched nutrient solution for 40 days at $10^{\circ} \mathrm{C}$ in the slow growing phase, and for 5,7 and 10 days at $20^{\circ} \mathrm{C}$ in the developmental phase at the beginning of formation of the flower stem. The concentration in leaves increased with time during plant growth, and in Se treated groups was 370 and $139 \mathrm{mg} \mathrm{kg}^{-1}$ in 'Anivip' and 460 and 205 $\mathrm{mg} \mathrm{kg}^{-1}$ in 'Monivip' leaves after 40 and 10 days of exposure, respectively. A smaller increase in selenium content was obtained in roots, namely to 73 and $46 \mathrm{mg} \mathrm{kg}^{-1}$ in 'Anivip' roots and to 87 and $46 \mathrm{mg} \mathrm{kg}^{-1}$ in 'Monivip' roots after 40 and 10 days of exposure, respectively. All results are expressed on a lyophilised matter basis. In long and short term treatment, the selenium content in 'Monivip' cultivar was higher than in 'Anivip'. No visible toxic effects on the chicory plants were observed.
\end{abstract}

Key words: aeroponics, chicory, selenium, distribution, uptake

\section{IZVLEČEK}

\author{
PRIVZEM IN PORAZDELITEV SELENA V RADIČU \\ (Cichorium intybus L.), GOJENEM V AEROPONSKEM \\ SISTEMU
}

Gojene rastline so skromen vir selena $(<0,1 \mathrm{mg} / \mathrm{kg})$. Raziskovali smo vpliv selenata na privzem selena in njegovo porazdelitev $\mathrm{v}$ radiču (Cichorium intybus L.) kultivarjev 'Anivip' in 'Monivip'. Rastline so bile gojene aeroponično v rastlinjaku. Korenine rastlin smo škropili s Reshevo hranilno raztopino, ki je vsebovala $10 \mathrm{mg} \mathrm{Se}(\mathrm{VI}) \mathrm{L}^{-1} \mathrm{v}$ obliki natrijevega selenata, vsakih petnajst minut. Naredili smo dve pilotni študiji. V prvi študiji so bile rastline, ki so ob začetku poskusa imele 6 listov, izpostavljene 40 dni hranilni raztopini, ki je vsebovala $\mathrm{Se}(\mathrm{VI})$ pri temperaturi $10{ }^{\circ} \mathrm{C}$, v drugi pa 5,7 in $10 \mathrm{dni}$ pri temperaturi $20{ }^{0} \mathrm{C}$ in $\mathrm{v}$ razvojni fazi tik pred cvetenjem. Vsebnost Se je bila večja $\mathrm{v}$ listih kot $\mathrm{v}$ koreninah in je naraščala $s$ časom izpostavljenosti. Masni delež selena $v$ listih kultivarja 'Anivip' se je povečal od 55 na $139 \mathrm{mg} \mathrm{kg}^{-1}$ med petim in desetim dnevom izpostavljenosti, v kultivarju 'Monivip' pa od 78 na 205 mg kg-1. Vsebnost Se v koreninah je tudi naraščala, vendar so bile razlike med kultivarjema manjše. Pri 40 dnevni izpostavljenosti je bil masni delež Se $370 \mathrm{mg} \mathrm{kg}^{-1} \mathrm{v}$ listih in $73 \mathrm{mg} \mathrm{kg}^{-1} \mathrm{v}$ koreninah kultivarja 'Anivip' ter $460 \mathrm{mg} \mathrm{kg}^{-1} \mathrm{v}$ listih in $87 \mathrm{mg} \mathrm{kg}^{-1} \mathrm{v}$ koreninah kultivarja 'Monivip'. Vsi rezultati so izraženi na liofilizirano snov. Tako pri dolgi kot pri kratki izpostavljenosti rastlin hranilni raztopini s selenom je bila vsebnost Se v kultivarju Monivip večja kot pri kultivarju Anivip. Na rastlinah nismo opazili znakov zastrupitve.

Ključne besede: Aeroponsko gojenje, radič, selen, privzem, porazdelitev

\footnotetext{
1 Jožef Stefan Institute, Department of Environmental Sciences, Jamova 39, 1000 Ljubljana, Slovenia, *Corresponding author, tel.: +386 1588 5352, fax.: +386 1588 5346, E-mail: vekoslava.stibilj@ijs.si

2 Present address: Krka, d. d., Novo mesto, Šmarješka cesta 6, 8501 Novo mesto

3 Department of Agronomy, Biotechnical Faculty, University of Ljubljana, Jamnikarjeva 101, 1000 Ljubljana, Slovenia
} 


\section{INTRODUCTION}

Selenium is an essential micronutrient for animals, some prokaryotes and some eukaryotes, but its essentiality for the growth of higher plants has not yet been demonstrated (Ellis and Salt, 2003). Selenium intake in humans is low in many European countries such as Spain (Diaz-Alarcon et al., 1996), Turkey (Foster and Sumar, 1997), Poland (Wasowicz et al., 2003), Austria (Pfannhauser et al., 2000), Slovenia (Pokorn et al., 1998) and Croatia (Matek et al., 2000), and in some other parts of the world such as some regions of China (Combs and Combs, 1986). Plants generally contain low amounts of selenium, and besides this, contents vary depending on the plant species and the selenium level in the soil where they are grown.

Several studies have been carried out dealing with supplementing the amount of selenium in various plants. Poggi et al. (2000) studied the effect of foliar spraying of 0,50 and $150 \mathrm{~g}$ of $\mathrm{Se} \mathrm{ha}^{-1}$ in the form of sodium selenate and sodium selenite on potatoes. The selenium content in such potatoes exposed in this way markedly increased. Wheat, alfalfa and sunflower seeds were germinated for 5 and 7 days in solutions containing 0.78 to $800 \mathrm{mg} \mathrm{Se} \mathrm{L}^{-1}$ in the form of sodium selenate (Lintschinger et al., 2000). The production of sprouts containing a higher amount of selenium represented an additional increase in the generally high nutritional value of such sprouts. Stadlober et al. (2001) investigated if the selenium content of different kinds of cereals could be raised after application of fertilisers containing $30 \mathrm{mg} \mathrm{Se} \mathrm{kg}^{-1}$ soil as selenate. The selenium content in cereals increased from the range 0.006-0.024 $\mathrm{mg} \mathrm{kg}^{-1}$ in the control group to the range $0.168-0.238$ $\mathrm{mg} \mathrm{Se} \mathrm{kg}{ }^{-1}$ in the exposed group. Elles et al. (2000) tested if plants could serve as a source of more available selenium than inorganically based mineral supplements. For this purpose Indian mustard was grown under hydroponic conditions and the accumulated selenium possessed better solubility than mineral supplements. $\mathrm{Hu}$ et al. (2001) determined the effects of selenium treatments on the sensory and chemical quality of green tea. Sodium selenite and organically bound Se solutions were used as fertilizer sprays. The sensory quality e.g. astringent taste, bitterness, sweetness and aroma, and the chemical quality e.g. vitamin $\mathrm{C}$ content, total amino acid and polyphenol content, were significantly improved after treatment with selenium. By increasing the amount of selenium in plants a defensive role against external stress factors (UV-B radiation), a growth promoting response manifested as a decrease in lipid peroxidation, an increase in glutathione peroxidase activity and the enhanced growth of senescent ryegrass (Hartikainen et al., 2000) and lettuce (Xue et al., 2001) were confirmed. Seppänen et al. (2003) cited positive effects of selenium on photooxidative stress tolerance in selenium enriched potato.

In the literature only few data on selenium uptake in chicory could be found (Germ et al., 2007). Scotti et al. (1999) studied the effect of fly ash on the availability of metals like $\mathrm{Zn}, \mathrm{Cu}, \mathrm{Ni}$ and $\mathrm{Cd}$ to chicory.

Chicory has abundant growth and is usually cultivated for the production of inulin from leaves or roots. It is a plant whose roots store inulin with a high fructose content (about $94 \%$ ). It is also used as salad during the whole year and has many benefits such as low calorific properties and the ability to regulate intestinal flora (Figueira et al., 2004). It is very appropriate for different types of cultivation such as conventional cultivation, hydroponic and aeroponic cultivation; also after harvest plants can be stripped of their green leaves, stored in the cold and finally forced by warmth and humidity in complete darkness to develop chicory heads. Furthermore, it is insensitive to transport. Its consumption is very popular in Slovenia and in northern part of Italy. In Slovenia in the year 2008 an area of 204 ha was devoted to chicory cultivation and was for $16 \%$ bigger than in year 2002. (Statistical Yearbook of the Republic of Slovenia, 2010, http://www.stat.si/letopis/ 2010/16_10/16-12-10.htm)

The purpose of our work was to study the uptake and distribution of selenium in the chicory cultivars 'Anivip' and 'Monivip' after various periods and at various temperatures of treatment with selenium enriched nutrient solution. These are the two most frequently grown cultivars in Slovenia and are resistant to low temperatures, down to $-12{ }^{\circ} \mathrm{C}$.

\section{EXPERIMENTAL}

\section{Plant material and growth conditions}

We used the aeroponic system for chicory cultivation because of its many advantages. Aeroponics is a form of hydroponic plant cultivation in which the plant roots are suspended in a closed chamber and misted with a complete nutrient solution. Aeroponics requires no solid or aggregate growing medium and allows for easy access to the roots. The chamber and misting system provide complete control of the root zone environment, including temperature, nutrient level, $\mathrm{pH}$, humidity, 
misting frequency and duration, and oxygen availability. For preparation of $100 \mathrm{~L}$ of Resh nutrient solution, containing the macro- and microelements essential for the growth of leafy vegetables, Fe-EDTA (4.17 g), $\mathrm{CuSO}_{4} \cdot 5 \mathrm{H}_{2} \mathrm{O}(0.0393 \mathrm{~g}), \mathrm{MoO}_{3}(0.0075 \mathrm{~g}), \mathrm{MnSO}_{4}$ $(0.203 \mathrm{~g}), \mathrm{ZnSO}_{4} \cdot 7 \mathrm{H}_{2} \mathrm{O}(0.0044 \mathrm{~g}), \mathrm{H}_{3} \mathrm{BO}_{3}(0.286 \mathrm{~g})$, $\mathrm{Na}_{2} \mathrm{SO}_{4}(1.0 \mathrm{~g}), \mathrm{MgSO}_{4} \cdot 7 \mathrm{H}_{2} \mathrm{O}(40.5 \mathrm{~g}), \mathrm{KH}_{2} \mathrm{PO}_{4}(22.0$ g), $\mathrm{K}_{2} \mathrm{SO}_{4}(32.8 \mathrm{~g}), \mathrm{Ca}\left(\mathrm{NO}_{3}\right)_{2}(82.1 \mathrm{~g}), \mathrm{NH}_{4} \mathrm{NO}_{3}(14.2 \mathrm{~g})$ were used (Resh, 1995). $\mathrm{Na}_{2} \mathrm{SeO}_{4}$ (Sigma) (2.3949 g) was dissolved in water in a $100 \mathrm{~mL}$ flask and then transferred a $100 \mathrm{~L}$ plastic container, as used in the food industry, to reach a selenium concentration of $10 \mathrm{mg}$ selenium per litre of nutrient solution. Chicory (Cichorium intybus L.) cv. 'Monivip' and 'Anivip' (National list of varieties, p. 34-35, 2002, Ministry of Agriculture, Forestry and Food, Republic of Slovenia) were used and two experiments were performed under different climatic conditions and in various developmental phases of the plants.

\section{Long term treatment}

Seeds were cultivated in peat (Potgrond $\mathrm{H}$, Klasman, Geeste, Germany) and after 60 days 84 plants were transferred to the aeroponic system, where plants were placed in small pots, fixed with peat, but the roots left free in the air. The roots were sprinkling every 15 minutes with nutrient solution. After 90 days, plants were divided into two groups, 42 plants in control and 42 plants in exposed group. For treated group Se was added to the nutrient solution for the next forty days. At the time of $\mathrm{Se}$ addition to the nutrient solution, the plants had approximately 6 leaves. The average temperature in the greenhouse during winter was maintained around $10{ }^{\circ} \mathrm{C}$, by additional hot air heating when necessary. The temperature of the nutrient solution was maintained at $8-10{ }^{\circ} \mathrm{C}$. Slow growth occurred because of the low outside temperatures and light conditions in the winter period. At the end of experiment, each plant in the control or in the treatment group had approximately 10-12 leaves. 6 plants of each cultivar were taken for analysis. The nutrient solution in the plastic vessel was sampled on the first day and at the end of the trial.

\section{Short term treatment}

Plants were grown in the same way as in the long term experiment. Stone wool was used for fixation of plants. At the beginning of the short term treatment, the seedlings had been 180 days in the aeroponic system and 14 plants was used for each type of treatment. They had approximately 16 leaves and were in the development phase at the beginning of formation of the flower stem when selenate was added to the nutrient solution for 5, 7 and 10 days. The average temperature was $20^{\circ} \mathrm{C}$ with periodic increases above $20^{\circ} \mathrm{C}$. 4 plants of each cultivar were harvested for analysis. The nutrient solution in the plastic vessel was sampled every day during the trial and acidified with conc. $\mathrm{HCl}$ to $\mathrm{pH} 1$ and stored at $4{ }^{\circ} \mathrm{C}$ until analysis to prevent adsorption on the walls (Gomez Ariza et al., 2000).

\section{Sample preparation}

Plant leaves and roots were thoroughly washed with tap water to remove all superficial dirt as suggested by Markert (1995). Composite samples of 6 (first study) or 4 plants (second study) from both control and treated groups $(\sim 300 \mathrm{~g})$ were lyophilised (Christ, Alpha 1-4) at $-50{ }^{\circ} \mathrm{C}$ and 0.050 mbar pressure and then milled in an agate mill (Fritsch, Pulverisette 7) (speed: 6; time: 6 $\mathrm{min}$ ). The particle size was less than $0.2 \mathrm{~mm}$.

\section{Selenium determination \\ Plants}

The digestion procedure is described in detail elsewhere (Smrkolj and Stibilj, 2004).

0.150-0.200 $\mathrm{g}$ of sample was weighed in a Teflon tube. After that $0.5 \mathrm{~mL}$ conc. $\mathrm{H}_{2} \mathrm{SO}_{4}$ and $1.5 \mathrm{~mL} \mathrm{HNO}_{3}$ was added and heated for $60 \mathrm{~min}$ at $130^{\circ} \mathrm{C}$ in the screwcapped tubes in an aluminium block. After cooling, 2 $\mathrm{mL}$ of $30 \% \mathrm{H}_{2} \mathrm{O}_{2}$ was added and the tube reheated for $10 \mathrm{~min}$ at $115^{\circ} \mathrm{C}$, then $0.1 \mathrm{~mL}$ of $40 \% \mathrm{HF}$ was added and heated for 10 minutes at $115^{\circ} \mathrm{C}$, and again after addition of $2 \mathrm{~mL} \mathrm{H}_{2} \mathrm{O}_{2}$ the solution was kept at $115^{\circ} \mathrm{C}$ for $15 \mathrm{~min}$. By adding $2.5 \mathrm{~mL}$ of conc. $\mathrm{HCl}$ reduction of $\mathrm{Se}$ (VI) to Se (IV) at $100^{\circ} \mathrm{C}$ followed. The solutions were than diluted, depending on the foreseen selenium concentration in the samples.

\section{Nutrient solution}

$2 \mathrm{~g}$ of nutrient solution was weighed in a Teflon tube and then $2 \mathrm{~mL}$ of conc. $\mathrm{HCl}$ was added and reduction from $\mathrm{Se}(\mathrm{VI})$ to $\mathrm{Se}(\mathrm{IV})$ was performed in $6 \mathrm{M} \mathrm{HCl}$ media for $10 \mathrm{~min}$ at $100{ }^{\circ} \mathrm{C}$ and than diluted to $50 \mathrm{~g}$.

Precipitate occurring in the closed chamber with nutrient solution in the long term experiment

$0.8 \mathrm{~g}$ of precipitate was weighed in a Teflon tube. After that $1 \mathrm{~mL}$ of fuming $\mathrm{HNO}_{3}$ was added and the solution was heated for $30 \mathrm{~min}$ at $115^{\circ} \mathrm{C}$. Then $5 \mathrm{~mL}$ of $\mathrm{H}_{2} \mathrm{O}_{2}$ was added and heated for 30 minutes at $115{ }^{\circ} \mathrm{C}$, and finally $2.5 \mathrm{~mL}$ of conc. $\mathrm{HCl}$ was added and heated for $10 \mathrm{~min}$ at $100{ }^{\circ} \mathrm{C}$ for reduction of $\mathrm{Se}$ (VI) to Se (IV). The solution was than diluted to $50 \mathrm{~g}$.

In all cases selenium was detected in the digested solutions by HG-AFS (Smrkolj and Stibilj, 2004).

The accuracy of selenium determination was checked by analysing the standard reference material Trace Elements in Spinach Leaves, NIST 1570a. The mean result for 4 determinations was $113 \pm 4 \mathrm{ng} \mathrm{g}^{-1}$ and the certified value is $117 \pm 9 \mathrm{ng} \mathrm{g}^{-1}$. The repeatability of the determination of selenium was under $10 \%$ and the 
reproducibility $\left(\mathrm{RSD}_{\mathrm{R}}\right)$, calculated by ANOVA (Farrant, 1997), over a period of 8 months (38 determinations), for the determination of selenium in SRM Trace Elements in Spinach Leaves was $9 \%$. The detection limit was $0.14 \mathrm{ng} \mathrm{g}^{-1}$ solution.

Determination of macro and micro elements by $\mathbf{k}_{\mathbf{0}^{-}}$ instrumental neutron activation analysis ( $k_{0}$-INAA)

For $\mathrm{k}_{0}$-INAA, all irradiations were made in channels of the TRIGA Mark II reactor at the JSI: for short irradiation (ca 1 minute) in the pneumatic tube (PT) at a thermal flux of $3.5 \cdot 10^{12} \mathrm{n} \cdot \mathrm{cm}^{-2} \cdot \mathrm{s}^{-1}$, and for long irradiations in the carousel facility (CF) at a thermal flux of $1.1 \cdot 10^{12} \mathrm{n} \cdot \mathrm{cm}^{-2} \cdot \mathrm{s}^{-1}$ (irradiation time for each sample was $20 \mathrm{~h}$ ).

Aliquots of about $200 \mathrm{mg}$ of lyophilized samples were pressed into pellet form with a diameter of $10 \mathrm{~mm}$. A sample and standard (Al-Au(0.1\%) IRMM-530R disk 6 $\mathrm{mm}$ in diameter and $0.2 \mathrm{~mm}$ high) were stacked together and fixed in the polyethylene ampoule in sandwich form and irradiated long time in the CF of the TRIGA reactor, while for short irradiation only a sample and standard were irradiated together in the PT. Determination of $\mathrm{Al}, \mathrm{Cl}, \mathrm{Mg}, \mathrm{Mn}$ and $\mathrm{V}$ were made in the PT channel after short irradiation, while other elements were obtained after long irradiation in the CF of the TRIGA reactor. For peak area evaluation, the HyperLab program was used. For elemental concentrations and effective solid angle calculations a software package KAYZERO/SOLCOI ${ }^{\circledR}$ was applied. More details about the method used are given elsewhere (Jaćimović et al., 2002).

\section{RESULTS AND DISCUSSION}

\section{Long term treatment}

The results of the study showed that the selenium content in roots and leaves greatly increased after 40 days treatment with selenium enriched solution (Table 1). In leaves of the cultivar 'Anivip' the selenium content increased from 0.057 in the control group to 370 $\mathrm{mg} \mathrm{kg}^{-1}$ in the Se exposed group, and in the cultivar 'Monivip' from 0.047 in the control group to 460 $\mathrm{mg} \mathrm{kg}^{-1}$ in the $\mathrm{Se}$ exposed group. The selenium enrichment rate was lower in roots than in leaves; in the cultivar 'Anivip' the Se content increased from 0.022 to $73 \mathrm{mg} \mathrm{kg}^{-1}$ and in 'Monivip' from 0.069 to $87 \mathrm{mg} \mathrm{kg}^{-1}$. The cultivar 'Monivip' had a higher ability to take up selenium than 'Anivip'. The majority of the selenium was transported from roots to leaves. And in both cultivars a similar ratio (5-fold) between the Se content in leaves and roots was found.

Table 1 . Selenium content in chicory after 40 days treatment

\begin{tabular}{|c|c|c|c|c|}
\hline \multirow{3}{*}{ Group } & \multicolumn{4}{|c|}{$\begin{array}{l}\text { Se content in chicory after } 40 \text { days treatment } \\
\left(\mathrm{mg} \mathrm{kg}^{-1} \text { lyophilised sample }\right)^{a}\end{array}$} \\
\hline & \multicolumn{2}{|c|}{ ‘Anivip' } & \multicolumn{2}{|c|}{ 'Monivip' } \\
\hline & Roots & Leaves & Roots & Leaves \\
\hline Control & $0.088 \pm 0.036$ & $0.285 \pm 0.010$ & $0.276 \pm 0.076$ & $0.235 \pm 0.025$ \\
\hline Treated & $73 \pm 15$ & $370 \pm 90$ & $87 \pm 3$ & $460 \pm 70$ \\
\hline
\end{tabular}

The growth of treated plants was not diminished in comparison with control plants, and no reduction in dry matter content was found. The average content of moisture in leaves was $80 \%$ and in roots $75 \%$, irrespective of the group. From the Table 2 it is shown that the contents of essential elements Fe, K, Mn and $\mathrm{Zn}$ decreased and $\mathrm{Na}$ content increased in exposed chicory leaves, regardless of the cultivars. Fe is required in the formation of chlorophyll and acts as an activator of many biochemical processes (found in ferrodoxin and enzymes such as peroxidise, oxidation-rection processes). Excess $\mathrm{Zn}, \mathrm{Mn}, \mathrm{Cu}$ or Mo encourages $\mathrm{Fe}$ deficiency (Marchner, 2002). In our case, the Zn, Mn and $\mathrm{Fe}$ contents decreased, only Mo content slightly increased in Se exposed chicory leaves. The literature dealing the effect on distribution of essential metals according to Se accumulation in plants is scarce. Vogrinčič et al. (2010) found minor concentration changes of $\mathrm{Cd}, \mathrm{Mo}, \mathrm{Fe}, \mathrm{Mn}, \mathrm{S}$ in leaves, $\mathrm{Cu}$ in husks, $\mathrm{Mo}$ and $\mathrm{Mn}$ in inflorescences between buckwheat 
foliarly sprayed with $10 \mathrm{mg} \mathrm{Se}(\mathrm{VI}) \mathrm{L}^{-1}$ and control group. Addition of $\mathrm{Se}(\mathrm{VI})$ did not have any effect on concentration of Zn. Cuderman (2010) reported that the Fe content was approximately 30 times lower in Se enriched vegetables (chicory, dandelion, rocket, wild rocket), twice foliary sprayed with $\mathrm{Se}(\mathrm{VI})$ solution $(10+50) \mathrm{mg} \mathrm{L}^{-1}$ in comparison to control group. She found linear correlation between $\mathrm{Zn}$ and $\mathrm{Se}$ as well as between $\mathrm{Se}$ and Mo was obtained for all samples investigated. The $\mathrm{Zn}$ content was two or three times higher compared to non exposed leafy vegetables. No interdependence was observed by comparing control and $\mathrm{Se}$ enriched values obtained for $\mathrm{Mn}$ and $\mathrm{Cd}$. However, Pedrero et al. (2006) reported that radish exposed to $1 \mathrm{mg} \mathrm{L}^{-1} \mathrm{Se}(\mathrm{VI})$ or $\mathrm{Se}(\mathrm{IV})$ showed a slight decrease in the translocation of the $\mathrm{Mn}, \mathrm{Mo}$ and $\mathrm{Cu}$ when compared to control plants. Depending on the element, the decrease was more or less noticeable, but a tendency to reduce the translocation was observed when Se was supplied as Se(IV). No correlation was observed for $\mathrm{Cu}$ and $\mathrm{Zn}$. It was demonstrated that the chemical form of Se can influence the uptake and translocation of essential metals in radish plants, which could be the cause of the growth reduction of those plants grown in selenite media, in which the translocation were slightly poor (Pedrero et al., 2006).

Table 2: The element composition in non exposed and 40 days aeroponiccaly exposed chicory to nutrient solution with $10 \mathrm{mg} \mathrm{Se} / \mathrm{L}$, obtained by $\mathrm{k}_{0}$-INAA

Results are expresed in $\mu \mathrm{g} / \mathrm{g}$ of lyophilised sample.

\begin{tabular}{|c|c|c|c|c|c|c|c|c|}
\hline \multirow{4}{*}{ Element } & \multicolumn{8}{|c|}{ Leaves } \\
\hline & \multicolumn{4}{|c|}{ Non exposed } & \multicolumn{4}{|c|}{ Exposed } \\
\hline & \multicolumn{2}{|l|}{\begin{tabular}{|l|} 
ANIVIP \\
\end{tabular}} & \multicolumn{2}{|c|}{ MONIVIP } & \multicolumn{2}{|l|}{ ANIVIP } & \multicolumn{2}{|c|}{ MONIVIP } \\
\hline & Content & Unc. & Content & Unc. & Content & Unc. & Content & Unc. \\
\hline $\mathrm{Al}$ & 58.4 & 3.9 & 44.0 & 2.6 & 38.5 & 2.5 & 44.4 & 2.5 \\
\hline $\mathrm{Ba}$ & 4.35 & 0.58 & 2.77 & 0.17 & 1.68 & 0.42 & 1.16 & 0.35 \\
\hline $\mathrm{Br}$ & 12.0 & 0.4 & 10.9 & 0.4 & 10.6 & 0.4 & 8.74 & 0.31 \\
\hline $\mathrm{Ca}$ & 9329 & 329 & 6942 & 246 & 6540 & 308 & 8495 & 308 \\
\hline $\mathrm{Cl}$ & 10187 & 399 & 7763 & 330 & 8752 & 317 & 5995 & 214 \\
\hline $\mathrm{Cr}$ & 0.10 & 0.02 & 0.13 & 0.02 & $<0.16$ & & 0.13 & 0.04 \\
\hline $\mathrm{Fe}$ & 68.9 & 3.4 & 66.8 & 3.4 & 29.3 & 1.2 & 29.8 & 1.6 \\
\hline K & 55596 & 1962 & 52626 & 1858 & 46282 & 1655 & 35446 & 1282 \\
\hline $\mathrm{Mg}$ & 2826 & 117 & 2764 & 114 & 2764 & 126 & 3611 & 152 \\
\hline $\mathrm{Mn}$ & 56.0 & 2.0 & 39.8 & 1.4 & 17.2 & 0.6 & 13.9 & 0.5 \\
\hline Mo & 0.62 & 0.05 & 0.79 & 0.05 & $<1.2$ & & 2.42 & 0.27 \\
\hline $\mathrm{Na}$ & 644 & 23 & 527 & 19 & 732 & 26 & 1321 & 48 \\
\hline $\mathrm{Sr}$ & 49.1 & 2.4 & 37.9 & 2.1 & 43.0 & 1.7 & 57.3 & 2.5 \\
\hline V & $<0.5$ & & $<0.4$ & & $<0.4$ & & $<0.3$ & \\
\hline $\mathrm{Zn}$ & 111 & 4 & 137 & 5 & 51.7 & 1.8 & 44.1 & 1.6 \\
\hline
\end{tabular}

\section{Short term treatment}

To estimate the selenium uptake in 180 day old chicory plants, fixed in pots with stone wool under advantageous climatic conditions (higher temperature $\left(20^{\circ} \mathrm{C}\right)$ and more light), short term treatment was applied.

The selenium content in leaves increased with time during plant growth; the ratio between selenium contents in the groups treated for 5 and 10 days was the same for both cultivars (2.5 and 2.6) in the flowering period (Table 3).

In roots the selenium content increased with time during plant growth from 27 to $46 \mathrm{mg} \mathrm{kg}^{-1}$ for 'Anivip' and from 33 to $46 \mathrm{mg} \mathrm{kg}^{-1}$ for 'Monivip', all on a lyophilised basis (Table 3 ). Similar ratios between $\mathrm{Se}$ content in roots of plants treated for 5 and 10 days (1.7 for 'Anivip' and 1.4 for 'Monivip') were obtained. Sample preparation of roots was very difficult, since they were hard to clean due to their branched shape, so the representativeness of the sample was very hard to assure. This could be a possible reason for the lower selenium content found after 7 days of exposure than after 5 days for the cultivar 'Monivip'. In both treatments, selenium uptake was greater by the 'Monivip' than by the 'Anivip' cultivar. No difference in dry matter content in leaves and in roots was observed. Despite the high selenium concentrations, none of the organoleptic toxic effects described in the literature such as a smell of garlic, chlorosis, withering and drying of leaves, bleaching or yellowing of younger 
leaves, pinkish spots on roots or premature death of the plant (Kabata Pendias, 2001; Terry et al., 2000) were found in chicory plants, either in the short or in the long treatment group. In a very short time (5 days) a rather high Se accumulation was obtained and after 10 days the concentration approximately doubled in comparison to 5 days exposure. In 10 days approximately half of the concentration found after 40 days was accumulated. However, in the comparing the accumulation of $\mathrm{Se}$ in chicory in the both experiments, it should be considered that in the 40 day treatment the Se concentration in nutrient solution decreased due to Se containing precipitate.

Table 3. Selenium content in chicory leaves and roots after 5, 7 and 10 days of treatment with selenium enriched solution

\begin{tabular}{|c|c|c|c|c|}
\hline \multirow{3}{*}{$\begin{array}{c}\text { Time of } \\
\text { treatment with } \\
\text { Se enriched } \\
\text { solution } \\
\text { (days) }\end{array}$} & \multicolumn{4}{|c|}{$\begin{array}{c}\text { Se content in chicory } \\
\left(\mathrm{mg} \mathrm{kg}^{-1} \text { lyophilised sample }\right)^{a}\end{array}$} \\
\hline & \multicolumn{2}{|c|}{ 'Anivip' } & \multicolumn{2}{|c|}{ 'Monivip' } \\
\hline & Roots & Leaves & Roots & Leaves \\
\hline 5 & $27 \pm 1$ & $55 \pm 1$ & $33 \pm 2$ & $78 \pm 1$ \\
\hline 7 & $\begin{array}{c}32 \pm 2 \\
(1.2)\end{array}$ & $\begin{array}{c}123 \pm 3 \\
(2.2)\end{array}$ & $\begin{array}{c}23 \pm 1 \\
(0.7)\end{array}$ & $\begin{array}{c}130 \pm 8 \\
(1.7)\end{array}$ \\
\hline 10 & $\begin{array}{c}46 \pm 1 \\
(1.7)\end{array}$ & $\begin{array}{c}139 \pm 16 \\
(2.5)\end{array}$ & $\begin{array}{c}46 \pm 2 \\
(1.4)\end{array}$ & $\begin{array}{c}205 \pm 19 \\
(2.6)\end{array}$ \\
\hline
\end{tabular}

$\bar{a}$ - average \pm SD (ratio $=$ treated 7 or 10 days : treated 5 days ); The analysis of each sample was performed by fivefold determinations

Literature data on Se accumulation in vegetables are scarce, so for comparison of our results the studies on cultivation of vegetables in soil (Wrobel et al., 2004; Hartikainen et al., 1997) and in hydroponic system (Ximenez-Embun et al., 2004) with addition of various concentrations of selenium in the form of sodium selenate were used. The Se contents in leaves of hydroponically cultivated sunflower and lupine in selenate nutrient solution containing $5 \mathrm{mg} \mathrm{Se} \mathrm{L}^{-1}$ were in the same range (inside $100-800 \mu \mathrm{g} \mathrm{g}^{-1}$ ) as Se contents in chicory leaves after 10 days of selenium treatment in aeroponic system. (Table 4).

Table 4. Comparison of results of this work with literature data for the leaves of exposed plants

\begin{tabular}{|c|c|c|c|c|}
\hline Plant leaves & Type of cultivation & Se addition & $\begin{array}{c}\text { Se content } \\
\left(\mu \mathrm{g} \mathrm{g}^{-1}\right)\end{array}$ & Ref. \\
\hline $\begin{array}{c}\text { Onion } \\
\text { (Allium cepa) } \\
\end{array}$ & in soil & $\begin{array}{c}\mathrm{Na}_{2} \mathrm{SeO}_{4}\left(5 \mathrm{mg} \mathrm{L}^{-1}\right) \\
8 \text { days }\end{array}$ & $601 \pm 7$ & $\begin{array}{l}\text { Wrobel et al., } \\
2004 \\
\end{array}$ \\
\hline $\begin{array}{c}\text { Ryegrass } \\
\text { (Lolium multiflorum) }\end{array}$ & in soil & $\begin{array}{c}\mathrm{Na}_{2} \mathrm{SeO}_{4}\left(33 \mu \mathrm{g} \mathrm{kg}^{-1}\right) \\
21 \text { days }\end{array}$ & 5.05 & $\begin{array}{l}\text { Hartikainen et } \\
\text { al., } 1997\end{array}$ \\
\hline $\begin{array}{c}\text { Lettruce } \\
\text { (Lactuca sativa) }\end{array}$ & & $\begin{array}{c}\mathrm{Na}_{2} \mathrm{SeO}_{4}\left(33 \mu \mathrm{g} \mathrm{kg}^{-1}\right) \\
46 \text { days }\end{array}$ & 4.90 & \\
\hline $\begin{array}{c}\text { Lupine } \\
\text { (Lupinus albus) } \\
\text { Sunflower } \\
\text { (Helianthus annus) } \\
\end{array}$ & hydroponically & $\begin{array}{c}\mathrm{Na}_{2} \mathrm{SeO}_{4}\left(5 \mathrm{mg} \mathrm{L}^{-1}\right) \\
14 \text { days }\end{array}$ & $\begin{array}{r}609 \pm 12 \\
724 \pm 187 \\
\end{array}$ & $\begin{array}{l}\text { Ximenez- } \\
\text { Embun et al., } \\
2004\end{array}$ \\
\hline $\begin{array}{l}\text { Chicory cv. 'Anivip' } \\
\text { (Cichorium intybus) } \\
\text { Chicory cv. 'Monivip' } \\
\text { (Cichorium intybus) }\end{array}$ & aeroponically & $\begin{array}{c}\mathrm{Na}_{2} \mathrm{SeO}_{4}\left(10 \mathrm{mg} \mathrm{L}^{-1}\right) \\
10 \text { days }\end{array}$ & $\begin{array}{l}139 \pm 16 \\
205 \pm 19\end{array}$ & This study \\
\hline
\end{tabular}


Furthermore, we also studied the Se speciation in leaves of chicory ('Anivip') (Mazej et al., 2006). $64 \%$ of Se was accumulated in the water soluble form, irrespective of the time of exposure to Se enriched solution. Besides inorganic $\mathrm{Se}(63-73 \%)$, in the extracts after enzyme hydrolysis SeMet (4.2-8.4\%) and some unidentified peaks were observed. The compound $\mathrm{SeMeSeCys}$ was obtained (to $0.7 \%$ ) only in leaves of chicory that was 40 days exposed to Se enriched nutrient solution.

\section{Losses of Se during the experiments}

Although it was not the purpose of the experiments to perform a quantitative or mass balance study of selenium, we monitored the concentration of selenium in the nutrient solution during the short and long term treatments. In the latter, the actual concentration of $\mathrm{Se}$ in the nutrient solution fell considerably due to absorption on the contact surfaces of the chamber holding the nutrient solution and formation of a precipitate from an initial 10 to $4.52 \mathrm{mg} \mathrm{L}^{-1}$. We found that this precipitate contained around $20 \%$ of Se in a form of $\mathrm{Se}^{0}$ or in strong organic complex, soluble only in fumic nitric acid. These forms of Se could be a result of reaction with the humic substances present e.g. humic acids, fulvic acids and humins, that are known to be redox reactive and capable of reducing elements (Chen et al., 2003). Also the organic acids as root exudates are capable of reducing low levels of selenite or selenate in the immediate vicinity of roots (Shanker et al., 1996).

In the short term experiment, where the plants were fixed in pots only in stone wool, the Resh nutrient solution was sampled every day. The mean value of selenium content over the 10 days was found to be $7 \pm 1 \mathrm{mg} \mathrm{L}^{-1}, \mathrm{pH}=7.8$ and no precipitate was found. The decrease in selenium concentration in the nutrient solution was due to adsorption on plastic tubes and on the walls of reservoir at $\mathrm{pH} 7-8$. This was confirmed by a laboratory experiment, in which we prepared a $10 \mathrm{mg}$ $\mathrm{SeL}^{-1}$ solution in a polyethylene reservoir and found $6.8 \pm 0.2 \mathrm{mg} \mathrm{L}^{-1}$ after 10 days.

To conclude, chicory has the capability to take up a great amount of $\mathrm{Se}(\mathrm{VI})$ independently of the cultivation temperature and development phase. To cultivate selenium enriched chicory as a potential beneficial supplement aeroponically, more experiments are needed to define the appropriate duration of cultivation and the concentration of selenium in the nutrient solution.

\section{ACKNOWLEDGEMENTS}

We thank to Prof. Ivan Kreft, the Department of Agronomy, Biotechnical Faculty, University of Ljubljana, for his helpful discussions in preparation of the manuscript. This research was financially supported by Program P1-0143 and project J4-3416.

\section{REFERENCES}

Chen J., Baohua G., Royer R.A., Burgos W.D. 2003. The roles of natural organic matter in chemical and microbial reduction of ferric iron. Sci. Total Environ., 307: 167178 .

Combs G.F., Combs S.B. 1986. In The Role of Selenium in Nutrition. Academic Press, Orlando, San Diego, New York. 532.

Cuderman P. 2010. Selenocompounds in selenium-enriched plants determined by spectrometric methods. Doctoral dissertation, Ljubljana.

Diaz-Alarcon J.P., Navarro-Alarcon M., Lopez-Garcia de la Serrana H., Lopez-Martinez M.C. 1996. Determination of selenium in cereals, legumes and dry fruits from southeastern Spain for calculation of daily dietary intake. Sci. Total Environ., 184: 183-189.

Elles M.P., Blaylock M.J., Huang J.W., Gussman C.D. 2000. Plants as a natural source of concentrated mineral nutritional supplements. Food. Chem., 71: 181-188.
Ellis D.R., Salt D.E. 2003. Plants, selenium and human health. Curr. Opin. Plant Biol., 6: 273-279.

Farrant T.J. 1996. Practical Statistics for the Analytical Scientist. LGC, Teddington, 21-27.

Figueira G.M., Park K.J., Brod F.P.R., Honorio S.L. 2004. Evaluation of desorption isotherms, drying rates and inulin concentration of chicory roots (Cichorium intybus L.) with and without enzymatic inactivation. J. Food Eng., 63: 273-280.

Foster L.H., Sumar S. 1997. Selenium in health and disease: a review. Crit. Rev. Food Sci. Nutr., 37, 3: 211-228.

Germ M., Stibilj V., Osvald J. and Kreft I. 2007. Effects of selenium foliar application on chicory (Cichorium intybus L.). J. Agric. Food Chem., 55: 795-798.

Gomez Ariza J.L., Morales E., Sanchez-Rodas D., Giraldez I. 2000. Stability of chemical species in environmental matrices. Trends Anal. Chem., 19: 200-209. 
Hartikainen H., Ekholm P., Piironen V., Xue T., Koivu T., Yli-Halla M. 1997. Quality of the ryegrass and lettuce yields as affected by selenium fertilization. Agric. Food Sci. Fin., 6: 381-387.

Hartikainen H., Xue T., Piironen V. 2000. Selenium as an anti-oxidant and pro-oxidant in ryegrass. Plant Soil, 225: 193-200.

Hu Q., Xu J., Pan G. 2001. Effect of selenium spraying on green tea quality. J. Sci. Food Agric., 81: 1387-1390.

Jaćimović R., Lazaru A., Mihajlović D., Ilić R., Stafilov T. 2002. Determination of major and trace elements in some minerals by $\mathrm{k}_{0}$-instrumental neutron activation analysis. J. Radioanal. Nucl. Chem., 253: 427-434.

Kabata Pendias A. 2001. Trace Elements in Soils and Plants. 3rd ed. P. 313, CRC Press, Boca Raton.

Lintschinger J., Fuchs N., Moser J., Kuehnelt D., Goessler W. 2000. Selenium-enriched sprouts. A raw material for fortified cereal-based diets. J. Agric. Food Chem., 48: 5362-5368.

Markert B. 1995. Sample preparation (cleaning, drying, homogenisation) for trace element analysis in plant matrices. Sci. Total Environ., 176: 45-61.

Marschner H. 2002. Mineral Nutrition in higher plants. 2th edition., Elsevier Science Ltd., Academic press, 229-436.

Matek M., Blanuša M., Grgić J. 2000. Determination of the daily dietary selenium intake in Croatia. Eur. Food Res. Technol., 210: 155-160.

Mazej D., Falnoga I., Veber M., Stibilj V. 2006. Determination of selenium species in plant leaves by HPLC-UV-HG-AFS. Talanta, 68: 558-568.

Pedrero Z., Madrid Y., Camara C. 2006. Selenium species bio accessibility in enriched radish (Raphanus sativus). A potencial dietary source of selenium. J. Agric. Food Chem., 54, 2412-2417.

Pfannhauser W., Sima A., Heumann S., Schaller U., Wilplinger M., Schönsleben I. 2000. Estimation of trace element supply in Austria. In Metal Ions in Biology and Medicine. Centeno J.A., Collery P., Vernet G., Finkelman R.B., Gibb H., Etienne J.C. (Ed.), John Libbey Eurotext, Paris, 521-523.

Poggi V., Arcioni A., Filippini P., Pifferi P.G. 2000. Foliar application of selenite and selenate to potato (Solanum tuberosum): Effect of a ligand agent on selenium content of tubers. J. Agric. Food Chem., 48: 4749-4751.

Pokorn D., Stibilj V., Gregorič B., Dermelj M., Štupar J. 1998. Elemental composition ( $\mathrm{Ca}, \mathrm{Mg}, \mathrm{Mn}, \mathrm{Cu}, \mathrm{Cr}, \mathrm{Zn}, \mathrm{Se}$, and I) of daily diet samples from some old people's homes in Slovenia. J. Food Compos. Anal., 11: 47-53.
Resh H.M. 1995. Hydroponic food production, a definitive guidebook of soilless food-growing methods. Woodbridge Press Publishing Company, Santa Barbara, 527.

Scotti I.A., Silva S., Botteschi G. 1999. Effect of fly ash on the availability of $\mathrm{Zn}, \mathrm{Cu}, \mathrm{Ni}$ and $\mathrm{Cd}$ to chicory. Agric. Ecosyst. Environ., 72: 159-163.

Seppänen M., Turakainen M., Hartikainen H. 2003. Selenium effects on oxidative stress in potato. Plant Sci., 165: 311319.

Shanker K., Mishra S., Srivastava S., Srivastava R., Dass S., Prakash S., Srivastava M.M. 1996. Study of mercuryselenium interactions and their impact on $\mathrm{Hg}$ uptake by the radish (Raphanus sativus) plant. Food Chem Toxic, 34: 883-886.

Smrkolj P., Stibilj V. 2004. Determination of selenium in vegetables by hydride generation atomic fluorescence spectrometry. Anal. Chim. Acta, 512: 11-17.

Stadlober M., Sager M., Irgolic K.J. 2001. Effects of selenate supplemented fertilisation on the selenium level of cereals-identification and quantification of selenium compounds by HPLC-ICP-MS. Food Chem., 73: 357366.

Statistical Yearbook of the Republic of Slovenia. 2010. Statistical Office of the Republic of Slovenia. http:/www.stat.si/letopis/2010/16_10/16-12-10.htm

Terry N., Zayed A.M., Souza M.P., Tarun A.S. 2000. Selenium in higher plants. Annu. Rev. Plant Physiol. Mol. Biol., 51: 401-432.

Vogrinčič M., Cuderman P., Kreft I., Stibilj V. 2010. Effect of selenium foliar spraying on Se-compounds and some essential elements present in common buckwheat. 9th International Symposium on Selenium in Biology and Medicine, Selenium 2010, Kyoto, p. 091.

Wasowicz W., Gromadzinska J., Rydzynski K., Tomczak J. 2003. Selenium status of low-selenium area residents: Polish experience. Toxicol. Lett., 137: 95-101.

Wrobel K., Wrobel K., Kannamkumarath S.S., Caruso J.A., Wysocka I.A., Bulska E., Swiatek J., Wierzbicka M. 2004. HPLC-ICP-MS speciation of selenium in enriched onion leaves-a potential dietary source of Semethylselenocysteine. Food Chem., 86: 617-623.

Ximenez-Embun P., Alonso I., Madrid-Albarran Y., Camara C. 2004. Establishment of selenium uptake and species distribution in lupine, Indian mustard and sunflower plants. J. Agric. Food Chem., 52: 832-838.

Xue T., Hartikainen H., Piironen V. 2001. Antioxidative and growth-promoting effect of selenium on senescing lettuce. Plant Soil, 237: 55-61. 